\title{
Speaking About The Unspoken: Saudi Culture and Islamic Law in Antony Thomas's Docudrama Death of a Princess
}

\section{Amany El-Sawy}

To cite this article: El-Sawy, A. (2018). Speaking about the unspoken: Saudi culture and Islamic law in Antony Thomas's docudrama death of a princess. Al Raida, 42(2), 57-86. DOI:

10.32380/alrj.v42i2.1742

To link to this article: http://dx.doi.org/10.32380/alrj.v42i2.1742

(C) 2018 The Author(s)

Corresponding author: Amany El-Sawy

Author contact:amany-elsawy@alexu.edu.eg

Article type: Article

Article accepted: 24th October 2018

Published online: $30^{\text {th }}$ November 2018

Publisher: Institute for Women's Studies in the Arab World

Publication support provided by: Escienta

Journal ISSN: 0259-9953

Copyright: This is an Open Access article, free of all copyright, and may be freely reproduced, distributed, transmitted, modified, built upon, or otherwise used by anyone for any lawful purpose. The work is made available under the Creative Commons Attribution (CC-BY) 4.0 license. 


\section{Speaking About The Unspoken: Saudi Culture and Islamic Law in Antony Thomas's Docudrama Death of a Princess}

\section{Amany El-Sawy}

Department of English Language and Literature, Faculty of Education, Alexandria University, Egypt

Introduction

During recent decades, third world countries, especially Arab nations, have become concerned about their image in Western mass media. Arab commentators claim that coverage of their region "is often one-sided and one-dimensional" (Al-Nowais, H.E.A., 1980), and that their cultural characteristics have been falsely depicted. Such misrepresentation is one factor that leads Western viewers to misunderstand the social and political norms of the Arab world. Islam, as both a religion and a political force in Arab nations, is frequently misinterpreted. The topic that has most recently crystallized concern about the misrepresentation of Arab culture has been the role of women in Islamic societies. This paper tries to examine such misrepresentations, and to highlight Saudi culture and Islamic law, through an analysis of Antony Thomas's docudrama Death of a Princess.

To challenge one-sided representations of the Arab world, a number of Arab lobbying groups have been established to reflect the political views of the Arab community in the United States. One lobbying group, the American-Arab Anti-Discrimination Committee, addressed the topic "Media Perceptions of the Arab World" at its 1984 convention in Washington, DC. The speakers strongly emphasized their concern at the distorted image of Muslims in general and Arab women in particular. They argued that this distortion was intentional on the part of the American 
media. The misrepresentation of Islam-the predominant religion in the Middle East-was considered to be politically motivated and to reflect the strength of the Jewish lobby in the United States. As Professor Jack Shaheen explained:

I think the ugly Arab image exists in part because of ignorance, indolence, and fear - fear of pressure groups that consider any balanced view of Arabs to be Arab propaganda. But the negative image generally persists because no Arab-Americans are an integral part of the creative force in Hollywood that writes and produces entertainment. (22)

The stereotypes of Arabs in entertainment shows, Shaheen continued, "depict Arabs as cruel, cowardly and decadent people. Arab leaders... are seen as men who are either bloodfeuding Bedouins or oil blackmailers. They're depicted as sex-starved pimps, cheats and backstabbers" (22). Shaheen supported his points with numerous examples from TV entertainment programs. For example, in one episode of One Day at a Time, one of the main female characters participated in a demonstration against the arrival of an Arab at an airport. She was protesting because she felt that Arabs were buying up the country and that their oil money was responsible for inflation and world chaos (24). "Stereotyping tends to be self-perpetuating," Shaheen explained. "These pictures of Arabs reinforce and sharpen viewer prejudices" (27).

A stereotype can be defined as a "standardized picture held in common by members of a group representing an oversimplified opinion, or uncritical judgment" (Webster, N. \& Gove, P.B., 1968) of another group. Stereotyped groups are usually minority or ethnic groups within or outside of a particular society (Berelson, B. \& Steiner, G.A., 1964). Due to their cultural differences, they can become subject to prejudice, discrimination, or misjudgment. For example, Lippmann asserts that members of a stereotyped group can become victims of judgments by another group when their moral codes and philosophies differ (82-85). Insensitivity and inattentiveness on the part of one group in relation to another's cultural context intensifies pre-existing stereotypes.

Stereotypes of a society tend to be presented by mass communications media such as television (Berelson, B. \& Steiner, G.A., 1964). Through a network of verbal and visual images, the medium of television can create common standards. These common standards in international 
communications can lead to the misrepresentation of one culture to another as part of the stereotyping process (Hopkinson, T., 1980). The process of media stereotyping also "simplifies perceptual judgment by extending generalizations concerning one aspect of a person" (Patton, B.R. \& Giffin, K., 1981) to characterize and portray a total societal context.

Lippmann calls stereotypes "pictures in the head" that permit viewers to make classifications quickly and easily by providing ready-made compartments in which to place people (Patton, B.R. \& Giffin, K., 1981). The issue that has been most recently at stake in the misrepresentation of Islamic culture and religion is the role of Muslim women in society. Arab women, according to Western stereotypes, are "backward, live in harems, wear veils, and are stoned to death if they commit adultery" (Shaheen, J., 1980). The ever-present black veil provides a tangible visual symbol of the differences between Western women and their Arab counterparts. The veil appeals to television's need for visual symbols, and consequently Western media organizations have focused on the role of women as a way of portraying the differences between the two societies (Patton, B.R. \& Giffin, K., 1981).

The portrayal of Arab women by Western media organizations has frequently offended Saudi women. For example, the wife of a former Saudi ambassador to the United States, Nouha Al-Hegelan, complained: "Arab women are, unfortunately, victims of the stereotyping process. There is little understanding of either our status as women or the total context of our lives" (AlHegelan 5). As these comments indicate, Arabs intend to address the problem of media misrepresentation more aggressively in the future. In order to shed light on the problem of the portrayal of Arab culture by the American media, this paper examines how Saudi women were portrayed in Death of a Princess, which attempted to unravel important aspects of Arab culture, the Islamic faith, and the status of Arab/Muslim women. However, Death of a Princess, a docudrama aired on PBS in the United States on May 12, 1980, prompted vehement criticism from Saudi officials, who claimed their culture was grossly misrepresented by the film.

Thomas's Journey of Revelation 
Antony Thomas was an established documentarian known for such films as The South African Experience, The Arab Experience, The Search for Sandra Laing, and Holy Growth. He became interested in the story of the execution of a Saudi princess well after the incident had happened in July 1977. The execution of the princess and her lover was not reported in the Western media until a brief article appeared in a British newspaper six months after the execution occurred. The story was covered by other Western media organizations after it first appeared in Britain. Thus Thomas was not the first to break the story in the Western media; instead, he began his investigation only after other media organizations had run the sensational story of the public execution of a Saudi princess. "Although reporting of the incident was suppressed in Arab countries," John O'Connor of The New York Times explained, "the story gained wide circulation through word-of-mouth" (37).

Thomas traced his own interest in the story to a chance dinner conversation with a wellconnected Arab host in London. Thomas saw the princess as a symbol of the whole Arab predicament-a symbol that would allow him to examine many aspects of the Middle East, not least of which was the role of women in Islamic society (O'Connor, J. J., 1980). The investigation could also lead to insights about the overall political atmosphere surrounding the Saudi government and its Islamic system of justice. As David Fanning, the US executive producer of Death of a Princess, explained, the film was intended as "a serious and concerned journey into the Arab world."

Thomas and Fanning decided to make a film not directly about the princess, but rather about the process of tracking down her story. The decision was dictated by pragmatic considerations, not artistic ones. As Fanning explained, "almost none of the people depicted by actors in the film would have agreed to appear on camera" (O'Connor, J. J., 1980). However, Fanning did describe any attempts he and Thomas made to persuade key persons to appear. Thomas and Fanning spent five months in 1978 interviewing those who had known the princess, and they based their script on the interviews. The interviewees' reluctance to appear on camera prompted Thomas to employ the docudrama format. Events were recreated and reenacted, not simply recorded. While the script was based on interviews, its creation involved a great deal of personal interpretation on the director's part. This fact was never explicitly mentioned or 
recognized in the docudrama. Instead, Fanning argued that the docudrama form combined "a rigorous concern for facts that characterized the best of journalism with the narrative strength and dramatic thrust of a screenplay" (O’Connor, J. J., 1980).

Thus Thomas's investigation began well after the event had been reported in a number of Western newspapers, and his main interest was in describing the process of investigation rather than the event itself. As a result, Death of a Princess became a story about an individual's quest to understand a newsworthy event that seemed unusual and mysterious to a Western observer. As my analysis will reveal, the film was clearly the journey of one individual.

\section{The Form of Death of a Princess}

Thomas's goal in Death of a Princess was to document his own investigative process. He focused on his own detective work, not on Saudi women's viewpoints. Saudi women describing their own social values were not presented until the later part of the film, after Thomas's personal interpretation of the event had already been firmly established. The audience was not placed in the role of first-hand experiencers of the events. Instead, all the facts were filtered through Thomas's personal interpretations, and the director of the film became its central character.

The scenes in Death of a Princess were organized into a narrative that jumped from one point in time to another. Flashbacks occasionally interrupted the overall time structure of the film as events were recreated. With the exception of these flashbacks, the major scenes of the docudrama changed as Thomas changed the geographical locations of his investigation. Death of a Princess began with interviews in London, and then moved to interviews in Beirut. The film concluded by recreating Thomas's interviews in Saudi Arabia. The ordering of scenes resulted in the foregrounding of Western interpretations of the event, since these were offered first; nonSaudi opinions were offered second. As my analysis will reveal, Thomas's interpretation of Saudi culture from a Western perspective had been firmly established before he even began his investigation in Saudi Arabia.

Death of a Princess consisted of two parts. The first hour of the film performed three functions. It provided necessary background information about the execution itself and presented 
the official Saudi version of the event. Secondly, it explained the process Thomas used to attempt to confirm the story by traveling to Beirut. Finally, it examined the lifestyle of the royal family. The second half of the film presented a different version of the princess than the one developed through Thomas's initial investigation. Next, it depicted the political and administrative system in Saudi Arabia. By the end of the docudrama, the official Saudi version of events had been refuted. Thomas, as a Western observer, was left confused, angry, and shocked at the Saudi system. The following discussion will examine particularly significant scenes within each of these segments of the film.

\section{Documenting the Event and the Official Saudi Version}

The first 20 minutes of Death of a Princess provided background information on the execution and on Thomas's interest in the event. Six scenes were particularly significant in this segment of the film. First, the execution was presented. Second, the official Saudi version of the event was presented through a dinner conversation in London. Third, Thomas established the broader importance of the event through a conversation with an Arab friend who commented that the princess's story was symbolic of the whole Arab predicament. Next, Thomas interviewed the construction worker who had witnessed the execution and given the story to Western newspapers. To complement the construction worker's comments, Thomas interviewed an English nanny who knew the princess and the lifestyle of the royal family. Finally, this portion of the film concluded by presenting Thomas's version of the story. Throughout this first segment, Thomas explored the princess's story from London. Western observers or non-Saudi Arabs were featured, rather than Saudis.

The opening shots of Death of a Princess showed a crowd of Saudis from behind. A Western observer turned away from whatever the crowd was watching and ran toward the camera. His Western clothing distinguished him from the Arabs in their traditional white robes. As gunshots rang out, the camera zoomed into a close-up of the Western man's face. His expression reflected fear and shock. In this way, Thomas visually represented a Western reaction to the execution. The next shots were blurred stills of the execution, similar to those that had appeared in Western 
magazines such as Time. The sound of a telex machine accompanied subtitles such as: "I SAW A PRINCESS DIE..." (Thomas, Transcript). A red screen over the photos created visual interest while other titles appeared: "PRINCESS EXECUTED FOR LOVE"; "LA PRINCESSE, L' AMANT... ET LE BOURREAU”; "KOPF AB!". Finally, the title of the documentary appeared: "DEATH OF A PRINCESS, A film by Antony Thomas based on interviews recorded in London, Paris, Beirut and Arabia between July and November 1978" (Thomas, 1980, 1).

In the 55-second opening scene, Thomas presented the execution and a Westerner's shocked reaction to it. The images were highly dramatic and likely to capture the viewer's attention. The sound of the telex machine suggested the international implications of a newsworthy event. The headlines indicating that the princess had died for love conveyed the sensational nature of the execution. The red filter over the stills implied danger and bloodshed. The close-up of the man's face encapsulated the reaction of a Western audience to one extreme aspect of Saudi culture and Islamic law. The shocked reaction presented in the first minute of the film was consistently repeated throughout the rest of the film. In this way, the opening scene established the emotional tone that would permeate the rest of the film.

Death of a Princess was clearly scripted with dramatic effect in mind. This was evident in the opening seconds of the film. Viewers were offered a vivid presentation of the execution. The opening scene indicated that Thomas was interested in presenting the whole of Saudi culture through the use of a single symbol: the execution of a Saudi princess. The problem with Thomas's approach was that the example he chose was not representative, and he did not immediately explain the event or provide a sense of the cultural context surrounding it. The symbol of a public execution was sensational for a Western audience. While the opening scene was effective in terms of capturing attention, it was not effective in providing a balanced view of the event. As a result, his portrayal sensationalized the event rather than explaining it.

In the process of capturing attention by recreating a highly dramatic and visual event, Thomas also drew an implicit conclusion about the nature of Saudi society. The example presented in the opening minute implied the brutality of Islamic justice. Islamic culture was presented as bloodthirsty, primitive, and uncivilized. The rest of the docudrama reinforced this initial impression. The implicit Western cultural values that led to this negative appraisal of another 
culture were never recognized or questioned during Thomas's personal quest for understanding. While the execution scene was accurate, it was not representative. Yet, it clearly established the persuasive intent of the film. A Western perspective would be used to make value judgments thereafter. In addition, the initial scene established the first-person perspective that Thomas used throughout the film. The opening shot led viewers to expect a personal interpretation of the event. Thomas was a central character in the film, appearing on camera more than any other characters, including the princess herself. From the outset, Thomas's interpretation-or misinterpretationof Saudi culture was the unifying factor throughout the film. His interest in the drama surrounding the event was also clearly evident.

Death of a Princess introduced the role of Saudi women by quoting the comments of a male Saudi government official. After the opening shot of the execution, the film focused on the official Saudi version of the execution. A subtitle informed viewers that the location was London. The role of the director was played by a character named Christopher Ryder. He had been invited to a dinner party because "somebody more important had probably dropped out" (Thomas, 1980, 1). In this scene, Ryder explained how he became interested in the princess's story: "it's curious how an after dinner conversation could open a trail that led me through five capitols, a civil war and the private lives of dozens of friends and strangers" (Thomas, 1980, 1).

While the guests were mostly Arabs, this was not visually apparent in the scene. Women were mixing with men, and all were dressed in Western designer clothes. Waiters hovered in the background. Wine flowed freely, as a close-up of a wine bottle with an Arabic label indicated. All of these activities were forbidden by Islamic law. The surroundings were luxurious, implying the benefits of oil wealth. This impression was reinforced when a telephone call from Washington was refused by the influential host, Saeed Badra. All of this indicated that these Saudis did not follow restrictive Islamic laws outside the boundaries of their own country. The theme of hypocrisy was subtly introduced by portraying the corruption of the royal family when not in Saudi Arabia.

Ryder was shown in close-up for the first time in this scene. He was slightly withdrawn throughout the dinner conversation. The expression on his face was one of evaluation and judgment as he listened to Badra's version of the princess's story. The close-ups of his face created a sense of closeness between Ryder and the audience, indicating the important role that Ryder's 
perspective would play throughout the docudrama. Throughout Badra's explanation, the camera focused on medium shots of the faces of the dinner guests and the host, who emphasized his points with his silverware. Obviously, Badra was accustomed to being listened to with rapt attention, as his tendency to interrupt other speakers indicated.

Badra's official version of the princess's story consisted of three major parts. First, Badra claimed that the princess's family had indulged her by allowing her to travel the world. Traveling was a rare privilege for a Saudi woman. Her grandfather, the king's eldest brother, was described as loving and generous. He had attempted to save her, Badra claimed, by advising her to avoid confessing her adultery. The royal family had been concerned about her welfare but constrained by Islamic law. The second aspect of Badra's story was that a trial had been conducted in accordance with Islamic law. In order to secure a conviction for adultery, there must be four male witnesses or eight female witnesses to the act of penetration. In the absence of witnesses, the accused must condemn herself by repeating three times in a court of law, "I have committed adultery." According to Badra, the princess had condemned herself by confessing her crime, even though her grandfather had tried to prevent her. Finally, Badra claimed the princess had been confused by her exposure to Western values during her time at Beirut University: "you can imagine the influences in Beirut-radical Arab politics, women's liberation, Palestinians, Western influences, all pulling and pulling in different directions" (Thomas, 1980, 3). Her problem, Badra asserted, stemmed from influences outside the country that were in direct conflict with her native cultural values. The rest of the film refuted each of these three points of Badra's story. Initially, however, Ryder accepted this version as the starting point of his investigation.

The third scene described the verification process Ryder followed. In a scene lasting two minutes and 15 seconds, Ryder shared Badra's story with a friend. Ryder explicitly indicated his concern with "the facts." His first step, he indicated, would be to "check a few facts" by interviewing "two people in England who gave interviews to the press" (Thomas, 1980, 5). Yet, while Ryder stated his concern with "the facts" a number of times during the docudrama, each interview scene began with his latest interpretation of the event. Interviewees were asked to confirm or expand this interpretation; they were not asked to begin with their own version of the 
princess's story. Their comments were always constrained by Ryder's initial presentation of his interpretation of "the facts."

Beyond establishing the verification process that Ryder followed, this scene attempted to connect the princess's story to broader problems in the Middle East. Although Ryder's Arab friend, Shaheen, was not a Saudi, he claimed that "I understand that girl, and I understand her family" (Thomas, 1980, 4). Her experience, Shaheen explained, was "the story of two-hundred million people. The whole Arab predicament. How much of our past must we abandon? How much of your present is worth imitating?" (Thomas, 1980, 4). Shaheen's own family was divided by problems in accommodating the West. His brother could not deal with his father, who "still believes the world is flat" (Thomas, 1980, 4). "You know, Christopher," Shaheen continued, "to survive as an Arab one has to become a schizophrenic. One has to learn to live in two worlds at once" (Thomas, 1980, 4). Shaheen illustrated the clash between Western and traditional Arab values. Nevertheless, he did not explain that this conflict occurred primarily in Arabs who had chosen to live in the West, as he had.

In this scene, Ryder attempted to demonstrate that the princess's story was indicative of the whole Arab predicament in striving to adjust to Western technology and the changes it brought. But although Shaheen was an Arab, he was not a Saudi. The unique characteristics of Saudi culture were blurred because Ryder did not differentiate between Saudis and other Arabs. Throughout the first part of the film, Ryder never explained how Saudi Arabia differed from other Arab nations. By allowing other Arabs to comment on the princess's story, Ryder ran the risk of confusing a Western audience that was likely unaware of the significant differences between Saudi Arabia and other countries in the region.

After talking with his Arab friend, Ryder interviewed Jackson, the construction worker who had observed the execution. Throughout this scene, Jackson's prejudices against Saudi culture were apparent. For example, he described the country as a "smelly tip. Rubbish all over the place. Brand new buildings, you know, falling apart. Cats running in and out. Stray dogs. Heat" (Thomas, 1980, 6). This description emphasized the allegedly primitive nature of Saudi society in comparison with Western countries. Obviously, Jackson had not enjoyed his stay in the country. Jackson's 
prejudices went unchallenged in Ryder's recreation of the events he related. The execution was shown for a second time through flashbacks to Jackson's observations. As he explained how he came to photograph the execution, the camera showed long shots of Saudis in traditional costume moving down a crowded street as armed guards stopped traffic. Sirens sounded in the background as the camera showed a long shot of sand being dumped onto an empty square. "They were coming out the mosques," Jackson explained. "It's funny, isn't it?" he continued. "Straight out of church, and off to see a bloke get chopped" (Thomas, 1980, 7). Jackson's comment implied that the execution was a religious event-the only time that religious observances were shown in the docudrama. Guards stood around the perimeter of the square, pushing the crowd back. These images created the sense of a repressive atmosphere. The camera cut back to Jackson's apartment as he pulled out actual pictures of the execution. The rest of the execution was reenacted after the stills used in the opening scene were repeated.

Jackson explained his experience in voice-overs while the camera showed the execution. "I thought it was just one guy that were gonna get it," he said, indicating his surprise that a woman was also publicly executed (Thomas, 1980, 8). Gunshots rang out as the camera focused on the impassive faces of Arabs in the crowd. Jackson was shown looking nervously over his shoulder at the "full-blown Arabs" watching him (Thomas, 1980, 8). The princess lay like "a black heap" in front of the pile of sand (Thomas, 1980, 9). After she had been shot-which was not actually shown on camera-her lover was dragged into the center of the square. "The guy's hands were tied behind his back. He looked as though he had been drugged or beaten up or something" (Thomas, 1980, 11). The brutality of the punishment was heightened by the fact that the lover was forced to watch the princess die: he was blindfolded only after she had been shot. This minor detail emphasized once again the cruelty of the Islamic religion. The executioner was "just dressed like any old Arab you'd see in the street" (Thomas, 1980, 11). This statement implied that any Arab could be an executioner. The executioner "didn't have a great big massive shining sword neither," Jackson continued (Thomas, 1980, 8). In fact, the sword was not very sharp. "Five blows, the lad still weren't beheaded. His head never did come off" (Thomas, 1980, 8). The camera shifted once again to the faces of the crowd passively watching as the executioner lowered his arm. The crowd reacted with applause once the princess and her lover were dead. Although the actual killings did 
not appear on screen, the execution was described in gruesome detail. The implicit Western value judgments throughout Jackson's comments were never explicitly examined; his prejudices were left unchallenged. By returning to violent scenes of the execution within the first 10 minutes of the film, Ryder emphasized the implicit message that the Saudis' Islamic religion was violent and uncaring.

The transition to the next scene was quite abrupt. The camera showed a Western woman in Arab dress reacting vehemently to Ryder's portrayal of the execution. "Damned hell, why do you keep picking on those people? Their only crime is that they are living centuries behind us" (Thomas, 1980, 10). This woman, the film revealed, was Elsa Gruber, the English nanny employed by the princess's grandfather. While Gruber provided Ryder with useful insights into the lifestyle of the royal family, she was portrayed as interested in using the story of the princess for financial gain by writing a book. Ryder indicated that there were many conflicting stories about the princess. While some people, such as Gruber, were concerned about advancing their own interests, Ryder implied that he alone was interested in discovering the facts behind the execution. His self-interest in producing the documentary was never mentioned.

The last scene in this segment showed Ryder again talking to Shaheen. By this point, Ryder's version of the story was firmly established: "I have seen the girl in a palace. I've seen her execution in a parking lot. Now I know that she met the boy in Beirut. I have to go there..." (Thomas, 1980, 14). This scene established the reason behind the next segment in war-torn Beirut. Ironically, Ryder was no longer asking questions but instead seeking confirmation of the story he had already generated through his interviews. Instead of functioning as a reporter and allowing others to tell their stories, Ryder had established his own interpretation of events.

In the first 20 minutes of the docudrama, Ryder explained the execution itself and how he came to be interested in it. Interestingly, however, he first concentrated on investigating the story from London. As a result, he talked mostly to Westerners about the event, or to Saudis who were living like Westerners in London. The standards of judgment applied were clearly those of the West, not of Saudi culture. Although Ryder was interested in the princess, he talked mostly to men and mostly to non-Saudis in the first segment of the film. By repeating gruesome scenes of the 
execution twice in the first 10 minutes, Ryder heightened the dramatic effect and also established a negative interpretation of Saudi culture that would be developed in later scenes.

\section{Pursuing the Story in Beirut}

In the second major segment of the first half of the film, Ryder continued his investigation by traveling to Beirut, where he had been told the princess had been a student at Beirut University. In this section of the film, Ryder undermined one of the key premises of Badra's story: by the end of his trip, Ryder had discovered that the princess had never attended Beirut University.

These scenes allowed Ryder to comment on broader political problems in the Middle East. The segment began with vivid images of the partially destroyed city of Beirut, which had once been called the Paris of the Middle East. An armed guard leaned into Ryder's taxi and asked to see his passport. The presence of armed guards implied military repression in the city. The impression was reinforced by the bombed-out scenes that Ryder passed on his way to the hotel. These initial scenes of war-torn Beirut echoed his friend Shaheen's comments about the Arab predicament: in Beirut, the transition from the old ways to the new had not been successfully negotiated.

As Ryder drove through the city, he mused: "how much would a girl here at the University have been affected by the pain of Beirut?" (Thomas, 1980, 15). Her struggle, Ryder implied, was connected to broader political problems in the region. This idea of the princess as a political symbol was explicitly developed in a scene where Ryder talked to Palestinians about the execution. Once again, Ryder began the discussion by delivering his version of events. His dinner companions then provided their interpretations. As one character explained, "this girl was like she was imprisoned in a camp... She was not free to move. Like the Palestinians... The only difference is that her camp was more comfortable" (Thomas,1980,17). Throughout the discussion, the princess was depicted as a political activist who had sacrificed her life for her principles, just as Palestinians were doing. Her experience in Beirut, another character asserted, "was the turning point in her life" (Thomas,1980, 17). A third speaker continued the same political theme, arguing, "I feel that deep down she was a revolutionary... Having the scandalous affair with the boy was her way of expressing her rejection, she had no other way" (Thomas,1980, 17). While emphasizing the 
oppression of women in Saudi Arabia, these characters also saw the princess as a victim of the same political process that oppressed Palestinians. Through this analogy between a Saudi royal princess and Palestinian refugees, the differences between Saudis and other Arabs were obscured.

After his dinner conversation with the Palestinians, Ryder talked with Elie Salhawi, a "professional gossip and raconteur with his own private network of informers and contacts" (Thomas,1980, 20). The conversation took place in a hotel in Beirut. The camera panned to show women in skimpy bikinis lounging around the hotel pool. As Ryder talked with Salhawi, wine was poured by a steward. These images illustrated Western influences in the Arab country of Lebanon. The freedom in Beirut, Ryder implied, might have greatly influenced the princess. Salhawi agreed with Badra's version of the princess's story, with one exception: he questioned the portrayal of her grandfather as kind and considerate. "The girl's grandfather," Salhawi explained, was "a typically reactionary prince, one of those who rode out of the desert, sword in hand"(Thomas,1980, 20). In addition, the prince was "one of the original Arab playboys... He used to do everything. A very notorious person" (Thomas,1980, 20). In this way, Ryder established the double standard that existed for Saudi men and women. When the prince had heard of what his granddaughter had done, Salhawi continued, "he flew into a rage. He thought she had besmirched his honor publicly" (Thomas,1980, 20). When his granddaughter followed his example, the old prince became enraged. Instead of attempting to save the princess, Salhawi claimed, the old prince was responsible for her death. Badra's initial description of a caring grandfather was undermined.

Ryder's last stop in Beirut was Beirut University, where he thought the princess had been a student. As Ryder walked to the office of a university official, the camera showed tranquil campus scenes. Women in Western dress relaxed on tree-lined lawns. They mingled freely with their male peers and smoked cigarettes as they talked together. A voice-over during the scene repeated Badra's statements about the radical influences in Beirut that had corrupted the princess; the images of the peaceful campus undercut his words about corrupting influences. In his conversations with a university official, Dr. Marouche, Ryder discovered to his surprise that the princess had never attended the university. Ryder confirmed this by checking with the university registrar. He asked the man to check his records once again to see if anybody with that name had been enrolled (Thomas,1980, 32). "Our records go back to 1870," the registrar explained; nobody 
by that name had been enrolled. Ryder's trip to Beirut, then, was a blind alley, since the princess had not been a student there. Another major aspect of Badra's story had been proven false.

In the 24 minutes during which the film explored the princess's story in Beirut, Ryder began to undermine a number of key assumptions in Badra's story. What emerged most clearly was the fact that the princess had not been corrupted by Beirut. The political turmoil in Lebanon was not the root of her discontent with the system under which she had grown up. While Ryder's Palestinian friends identified with the princess's struggle, there was no tangible evidence that she had been affected by their radical politics. In addition, Ryder undermined the kindly image of her grandfather by highlighting the sexual double standard. Throughout the segment, Ryder did not differentiate between Saudis and other Arabs. Instead, all the peoples in the region were presented as a monolithic group that shared similar characteristics.

\section{Examining the Royal Lifestyle}

After Ryder returned to London, he again talked with the nanny, Elsa Gruber. She confirmed that the princess had never been a student at Beirut University: "of course she was never at the university... Her mind was like a 15 -year-old, but her instincts, her feelings, that was different. In those things she was a woman" (Thomas,1980, 33). Clearly, Badra's assertion that the princess had been exposed to Western influences while at the university was incorrect. As Gruber indicated, educational pursuits were not a high priority for a royal princess. Throughout his scene with Gruber, Ryder explored the lifestyle of royal women. The wealth of the royal family was obvious from Gruber's comments. "Everyone had a palace in the capitol, another palace by the sea, and a palace in the mountains" (Thomas, 1980, 34). The palaces were full of divorcees whose ex-husbands had gone abroad to escape. Everyone but the servants would sleep until noon or later. After long parties the night before, the "palace was full of rubbish, a mess" (Thomas, 1980, 35).

In Ryder's discussions with Gruber, the boredom and uselessness of the royal princesses was emphasized. The princess had nothing to do except shop or watch TV. "And when she dresses," Gruber explained, "the servant has to lay out 11 costumes, so she can choose. And the 
servant has to go round to the boutique and bring back all the latest Paris fashions, all on approval" (Thomas, 1980, 38). The princess was not even serious about her religion, Ryder discovered. "Praying is for the daytime, when she slept," Gruber claimed. "In our palace," she continued, "praying was for the servants" (Thomas, 1980, 39). The princesses did not exercise either, except "hopefully, making love," Gruber explained. "What else could you do?" Gruber continued. "I mean, if you're so damn bored, caged up in those palaces. There is nothing else on your mind" (Thomas, 1980, 37). The corruption and hypocrisy of the royal princesses was emphasized throughout Gruber's descriptions of the royal lifestyle.

In this atmosphere, the princess "was always defiant" (Thomas, 1980, 39). She teased the servants by playing rock music that they hated; she flouted her grandmother's prohibitions by smoking cigarettes, an activity forbidden to Saudi women. If her grandmother smelled smoke, the princess would claim that Gruber was smoking. Thus the princess was defiant even in her own country. She was "something of a wild animal" (Thomas,1980, 14); "a free soul, she was like a bird," struggling to break free of her gilded cage (Thomas, 1980, 16).

In Ryder's portrayal of the royal lifestyle, the wealth of the royal family was evident. Yet, the descriptions implied that wealth led to great corruption. There were no strong family ties in any of the descriptions of the royal family. Babies were turned over to nannies to be raised, and husbands divorced their wives when they grew tired of them. The men were presented as unconcerned about their family responsibilities. They could leave and enjoy the freedom available to them in the West, while their wives were caged in palaces, unable to travel abroad without a guardian's permission. The divorced princesses led lives of utter boredom enlivened only by scandalous sexual escapades. They were without morals. Religious observance was only for the servants, who did not have the privileges of the royal family. The royal family was portrayed as universally corrupt. This portrayal was a gross distortion of reality. While the examples Ryder mentioned might have been accurate in the case of a single family, they were certainly not representative or typical of the whole royal family.

In terms of the storyline, the first hour of the film undermined two aspects of Badra's version of the execution. The princess had not been corrupted by Western influences during her 
time in Beirut; she had never studied there. In addition, Ryder indicated that the princess's family was not caring and kind. The first half of the docudrama closed by implying that Badra was trying to justify the execution by lying about the facts. Implicitly, the first hour of the film led viewers to expect Ryder's trip to Saudi Arabia to continue to refute Badra's story.

Nevertheless, the first half of the docudrama was confusing. A number of conflicting stories were introduced but not resolved. A viewer might not know which version to believe. Only an analysis of the implicit meanings behind the images reveals the film's consistent implication that Badra was lying. With the exception of Badra's version of the story in the dining room scene, no Saudis were quoted in the first hour of the docudrama. Instead, Thomas first interviewed Westerners who were involved with the event. No effort was made until later to explore the different cultural values that had led to Western misinterpretations of the event. When Thomas interviewed Arabs in the first hour of the film, they were likely to be Lebanese or Palestinians who did not necessarily reflect Saudi social values. Although Saudis are Arabs, their national characteristics should not be confused with those of other Arab nations. Thomas, however, made few distinctions between Saudis and other Arabs. In addition, he failed to explain the unique role of Saudi Arabia in the Islamic world. Finally, he failed to question the implicit value judgments in the comments of Westerners who had witnessed the event.

\section{Establishing a Different Version of the Princess's Story}

The second hour of Death of a Princess began by establishing a revised account of the princess's personality. It continued with Ryder's investigation in Saudi Arabia. Ryder no longer saw the princess as a revolutionary. His trip to Beirut indicated that she had never spent much time in the city and certainly had never been a student there. If she was corrupted by Western influences, it must have been during her occasional trips abroad. Gruber, for example, confirmed that the princess had traveled to England. During the visit, Gruber and the princess had stayed at a different hotel than her grandfather. At night, they "used to creep out of the hotel, down the back stairs, and have fun" (Thomas, 1980, 42). The princess had had a lover in England, Gruber explained, but she did not know if this lover had been the same man who was executed with her. The implication 
was that the princess had been promiscuous rather than swept away by an all-consuming love for one man. The implication that the princess had been sexually active with more than one lover was disgraceful for a member of the Saudi royal family.

After exploring the princess's trips to London, Gruber provided Ryder with details of the fateful day when the princess's indiscretions were discovered. The scene foreshadows the princess's later attempt to escape the city. "The whole palace had been evacuated," Gruber explained (Thomas, 1980, 43). Initially, the princess's family thought that she had drowned, because they found her clothes on the beach. When Gruber frantically tried to find out what had happened to her, the family refused to answer. Finally, Gruber received a call from Princess Hude. When Gruber asked about the princess, she was told: "she knew exactly what she was doing and the shame she brought to our family, and they had to be killed, both of them" (Thomas, 1980, 43). When Gruber persisted in asking what the family had done to the princess, she was informed: "they hurt her until she died" (Thomas, 1980, 44). In Gruber's description of the princess's disappearance, there was no mention of a trial. Gruber argued that there had to be a trial because of Islamic law, but no evidence was presented to support her statement.

Badra's initial portrayal of the princess's relatives was again undermined. The reason behind the princess's execution, Gruber revealed, was not the immorality of her affair. Rather, the princess had to die because her affair was public knowledge and could not be ignored by her royal relatives, who were concerned about their reputation. The public aspects of her actions brought shame on the family. Consequently, the princess died not because of immorality, but because of indiscretion. Her family was portrayed as heartless and uncaring. Their public image was important; religious teachings were secondary.

In the scene before Ryder visited Saudi Arabia, he had articulated a "totally different version of the girl" (Thomas, 1980, 45). The princess was not a rebel fighting for a cause, but a silly young woman who did not think about the consequences of her behavior. At this point, Ryder asserted that "half of Badra's story has gone. All that business about the confrontation. Was it just an act of her grand-father's vengeance?" (Thomas, 1980, 45). Shaheen, listening to Ryder, replied that there was more to the story than simply an act of vengeance. "The fate of the girl is symptomatic of a deep social conflict in the country. It's the women, you see, who are in the thick 
of it. Travel, money, exposure to Western values. It's had a much great effect on the women" (Thomas, 1980, 45). Thus the second part of the docudrama defined the execution as a deliberate political act on the part of the Saudi government to make one woman an example to others. This scene provided the rationale for Ryder's trip to Saudi Arabia.

\section{Examining the Saudi Political/Administrative System}

The first scenes in Saudi Arabia portrayed congested streets filled with American-made cars, pedestrians, and camels. The background music created a mood of tension and anticipation. Shots of modern buildings in the streets implied rapid development. Machines toiled side-by-side with manual laborers. Businessmen greeted each other in the lobbies of luxurious hotels or fought to gain access to overseas telephones. Signs of bustling commerce were everywhere. Nevertheless, the overall impression was of a system that did not work. Ryder, for example, could not place a call to the Ministry of Information. The desk clerk informed Ryder: "take a taxi, it's faster" (Thomas, 1980, 47). A Western audience would interpret these scenes as indications of mismanagement.

As Ryder drove through the streets, the camera showed Western consumer goods displayed in store windows. Billboards in English advertised American products such as Pepsi. Men in Arab dress walked through well-stocked stores full of furniture and electronics. A veiled woman paused in front of a display of the latest Western fashions. A poster showing a Western fashion model with bright red lipstick hung in a store window, providing a sharp contrast with the blackveiled women in the street. These scenes implied that Western influences were evident in Saudi Arabia. A young princess would not have to go to Beirut to be exposed to different values.

In his dealings with Saudi ministers, Ryder was constantly delayed. The ministers were not in their offices when they said they would be. Their attitude toward those who wanted to see them was one of arrogant disdain. In this way, Ryder indicated the problems inherent in obtaining access to information in Saudi Arabia. His investigation had proceeded more smoothly outside the country. 
In the first 20 minutes of the film, no Saudi women had been interviewed. Now, for the first time, Ryder talked to a native Saudi woman. The woman he talked to, Mme. Quataajy, owned a fashion boutique. The hypocrisy of the strict regulations in Saudi Arabia was illustrated by the fact that women came into her shop in their veils and instantly handed them to a servant. Ryder commented, "I don't understand the rules. I know women have to wear the veil in public, then I can walk in here and see them unveiled." The rules, Ryder implied, were inconsistently applied (Thomas, 1980, 49). The theme of corruption was reinforced by Mme. Quataajy, who indicated that some boutiques were used for "hanky-panky business" (Thomas, 1980, 49)-in other words, some women used the boutiques to meet their lovers. However, Mme. Quataajy defended Saudi rules and restrictions placed on women: "The veil is very feminine if you know how to wear it" (Thomas, 1980, 50). She appreciated the strict rules because they made Saudi Arabia safe. It was not like the West, where "burglars can come into your home and kill you and rob you and get the lightest punishment... Strong punishments make our country safe" (Thomas, 1980, 50). There "is some confusion," Mme. Quataajy admitted, but she was content with the system (Thomas, 1980, 49). Yet, her defense of the restrictions was undercut by the fact that she herself did not follow the rules prohibiting men and women from working together. She had a male assistant who worked for her, and she did not wear a veil to receive Ryder.

The next scenes dramatized Ryder's meetings with government officials. These officials echoed a similar theme: the reporting of the princess's execution was part of "a deliberate campaign against the Arabs" (Thomas, 1980, 51). One national newspaper editor even refused to comment on the princess's execution. In Arabic, he claimed that "everything that appears in the Western press is distorted, lies... Tell him that he is our guest, and it is not the business of a guest to interfere in our private domestic affairs" (Thomas, 1980, 52). The interpreter translated his comments as simply, "what princess?" (Thomas, 1980, 63). When Ryder went to the next government office, the Ministry of the Interior, it was clear that his previous conversation had already been reported to the minister. The press in Saudi Arabia functioned as an extension of the government and echoed the official line. The film implied that it was Saudi officials, not the Western press, who were guilty of distorting reality. 
As part of his investigation, Ryder visited the scene of the execution. He walked through the parking lot where the princess had been executed. Now the area was filled with cars and Arabs walking through the market. The white-robed men were easily distinguished from the black-veiled women. As Ryder walked along with a pensive expression, a voice-over repeated Jackson's account of the execution. The flashback reminded the audience of the earlier reenactment of the execution of a princess who had died for love. The images also implied that government officials had lied to Ryder in an effort to cover up the incident.

Ryder visited the Dar El Oloum girls' school where Shaheen's niece was a teacher. The camera showed veiled girls being driven to school. The background music conveyed a sense of doom as the veiled girls entered the dark gates of their school. The camera focused on the black doors as they closed behind the girls with a bang. The depressing dark colors in the long shots implied that the girls were entering a dungeon. Inside the school, however, the mood was very different. The girls were shown playing a spirited game of volleyball. Beneath their veils they were clearly normal adolescent girls who were free only within the tight confines of their segregated school.

Ryder's conversation with Samira, Shaheen's niece, was stiff and formal, watched by a chaperone from the Ministry of Interior. The chaperone appeared sinister as he listened to Ryder and Samira's conversation. Samira was veiled with a scarf around her head and was clearly conscious of the chaperone's eavesdropping. Ryder asked her: "what sort of a career can a woman choose in this country?" "A woman can choose any career she wishes, providing, of course, that the work doesn't bring her into contact with men," Samira answered (Thomas, 1980, 55). With the chaperone listening, Samira was forced to say things Saudi officials would approve. She went on to explain the educational system in Saudi Arabia. She stated that sometimes male lecturers would be invited to the college for the more advanced classes. The male speaker would give his lecture through closed-circuit television. If a student had a question, she could communicate with the speaker by telephone. Ryder asked, "by telephone?" Samira responded, "by telephone" (Thomas, 1980, 55). Samira was giving Ryder subtle hints, inviting him to contact her later by telephone. The scene implied that Saudis were not free to speak their minds in their own country because of government control over the information allowed to foreigners. 
The next scene showed Ryder visiting Samira in her apartment. As he walked to her door, a car containing government officials followed him. Obviously, he was under surveillance while pursuing his investigation. Such incidents contributed to the impression that Saudi Arabia was a closed society with an oppressive political system. The way Ryder was treated indicated a totalitarian regime, unlike those in Western European countries. In Ryder's private meeting with Samira, she was unveiled and dressed in jeans and a shirt. She was more animated and relaxed in this second conversation in her home. When Ryder asked if his presence would place her in danger, she replied, "oh no, I can take care of myself. Besides, we have a chaperone, my motherin-law" (Thomas, 1980, 56). Before they began talking, Samira asked Ryder to take a few letters she had written, implying that the mail was censored.

Lighting a cigarette, Samira asked Ryder, "are you really doing anything with the state of Arab women?" (Thomas, 1980, 56) When Ryder replied that he was examining the story of the princess's execution, Samira asked, "have you heard the true story?" "I've heard a dozen true stories," Ryder replied. Samira gave her version of the story: "this isn't a Muslim country. These people pervert Islam, they use Islam. They scare people to death with their barbarous illegal punishments" (Thomas, 1980, 58). The veil, Samira continued, was not required by Islam. It was a tradition instituted by the Turks to protect women against harsh weather conditions in the desert: "before Ottoman rule, Arab women led armies, were equal partners in marriage-until they were silenced by that veil" (Thomas, 1980, 58). When Ryder asked Samira if the princess had been fairly tried, she replied, "Of course she wasn't... They wanted to make an example out of her... Because she defied them" (Thomas, 1980, 58). The current Saudi regime, Samira continued, had nothing to do with Islamic thought, feeling, or ideology. Islam was democratic. There were no kings in Islam. The Quran said that leaders must be elected by the people, and that the people had the right to criticize them (Thomas, 1980, 59). In this scene, Ryder thus undermined another important tenet of Badra's version of the princess's execution: she did not receive a trial. Samira argued that Islamic legal procedures had not been followed in the case of the princess. The implied message was that the Saudi political system was corrupt in not following the dictates of Islam. 
The next scene concentrated once again on the personal corruption of the royal family. The Saudis found this scene of the film particularly objectionable and degrading. Samira introduced Ryder to a shadowy figure named Emira, supposedly a member of the royal family familiar with the incident. Throughout the scene, Emira's face remained in darkness, even though her name had been changed. This technique heightened the drama and suspense of her comments. She corroborated Gruber's comments about the dissolute lifestyle of royal princesses. According to Emira, royal princesses' only privilege was "sex. To relieve their boredom, these Princesses live the most intricate and busy sex lives. Very little romance. Quick liaisons. Sometimes cruel, always dangerous" (Thomas, 1980, 63). Emira described a desert road where princesses cruised in their cars to pick up casual lovers. She condemned these activities, not because of their immorality, but because of their hypocrisy. Emira revealed that the princess had met her lover in Saudi Arabia, just as other princesses met theirs. The only difference in the princess's case was that her relationship became public. "Poor child," Emira asserted. "Poor silly child. She paid for all of them" (Thomas, 1980, 64). Emira reiterated that the princess was punished as an example to other women. In this way, the film implied that the princess's corruption was widespread rather than an isolated case. The corruption came from influences within the country, not from without.

The next scenes in the docudrama recreated the princess's unsuccessful attempt to flee the country dressed as a man. There were no single women in the airport when the princess tried to escape. As she stepped through a metal detector, an alarm rang, prompting a guard to pull the keffiyeh off her head and revealing that she was a woman. As the guards questioned her in an office, her young lover ran in, thereby condemning himself also. As guards led her lover away, the frightened princess began to cry.

The last major scene in Ryder's trip to Saudi Arabia was a recreation of the Islamic court. A religious man who was an expert in the Quran's teachings was in charge of the court. He functioned as defense lawyer, prosecutor, and judge. There was no jury. The proceedings were explained in a voice-over. An American audience viewing the scenes of the courtroom would not recognize it as such without the narrative explanation: it looked like any other administrative office in Saudi Arabia. 
To further support his claim that the princess never received a trial, Ryder interviewed a legal expert. This cleric explained that "there was no trial. The execution was a matter of... public policy" (Thomas, 1980, 70). The couple were taken from the airport, he explained, to the grandfather's palace. "On the following Friday, they were executed by the Prince's own bodyguards" (Thomas, 1980, 70). The film implied that the execution was an act of personal vengeance on the part of the girl's grandfather. The official Square of Justice was not used for the execution; a parking lot was used instead.

By this point in the docudrama, all the major premises of Badra's version of the story had been proven false. The princess was not corrupted by outside influences. She met her lover in Saudi Arabia, and the influence of Western feminism had little to do with her rebellious behavior. Her royal family, rather than attempting to save her, were primarily responsible for her death. They were more concerned about their public image than about her welfare. Finally, Ryder's trip to Saudi Arabia convinced him that Islamic judicial procedures had not been followed. There had been no trial of the princess. She had been executed by her grandfather's bodyguards, not by an Islamic court. At the end of the film, the audience was left with the impression that the execution was the brutal, illegal act of a repressive, corrupt political regime. The royal family had not followed the traditional procedures for fair trial prescribed by Islam.

The closing scene showed Ryder back in London, talking again with his friend Shaheen. Ryder was clearly angry that Badra had lied to him: "why the bloody hell did Badra tell me that?" (Thomas, 1980, 71) It was naive of him, Ryder contended, to misrepresent the facts. Shaheen in return tried to explain the cultural gaps between Westerners and Arabs: "the difference between your world and mine is that most of us still search for inspiration, for belief. And above all, meaning. For you, life is defined by facts, details" (Thomas, 1980, 72). Ironically, however, Ryder had continually foregrounded his own interpretations, rather than presenting a balanced view of "the facts." In actuality, Ryder's quest was a search for meaning, not facts. That was the docudrama's whole raison d'être. Consequently, Shaheen's final distinction was quite misleading.

At the end of the film, Thomas looked sad, angry, and still confused about the event. "Damn it," he said, "I'm never going to get close to it" (Thomas, 1980, 71). Thomas himself had not generated an adequate explanation of the meaning of the event for a Western audience: 
"meaning! A 19-year-old girl was stuck in front of a pile of sand, and shot" (Thomas, 1980, 72). The film concluded with scenes of the princess dancing freely, reminding the audience that freedom had been denied to her in life. The end of the docudrama returned to the vivid, brutal image of the execution, without providing a deeper understanding of the social context that had led to it. In articulating his own confusion at the end of the film, Thomas also left the audience confused about the event. No clear resolution was offered at the conclusion of the docudrama. Islamic culture and Saudi values - ostensibly the focus of Thomas's investigation-were never adequately portrayed.

Overall, Death of a Princess made a number of implicit value judgments. The Saudi royal family was completely corrupt, the film implied. This corruption extended not only to individuals, but also to the country's whole political system. The conservative Islamic values that the Saudis preached were not practiced, and served only to hide the immorality of the royal family. Rather than accepting their own weaknesses, the Saudis blamed Western influence for their social problems. Throughout the presentation, the Saudi political system was portrayed as hypocritical and corrupt.

Saudi women were depicted as pawns of cruel and uncaring men. Their status was that of slaves, unable to travel freely or make basic decisions about their lives. The families portrayed in Death of a Princess were in the process of disintegration. Children were being raised by nannies, and husbands fled to the West while their wives remained caged in palaces. The life of a royal princess was one of boredom and uselessness, relieved only by the excitement of casual affairs. The strict rules governing Saudi women, the film implied, were not protections, but a means of maintaining political control over the masses. Women, abused by the system, were treated brutally when they dared to defy the restrictions.

Finally, Death of a Princess implied that the Islamic religion was brutal and cruel. The execution was the only aspect of the religion that was explained. The docudrama did not represent the extent of other religious observations in a country that is proud of its heritage as the birthplace of Islam. Only once were pilgrims shown at worship, and this was a brief scene on a TV screen in Ryder's hotel room. Without a broader knowledge of Islam, a Western viewer would not understand the importance of Saudi Arabia in the Muslim world as the protector of the holy places 
of Islam. Saudis see their role in the Islamic world as a privilege that they value highly. Death of a Princess explained Islamic attitudes toward public executions, but it did not even allude to the many positive aspects of the Muslim religion.

\section{Conclusion}

Antony Thomas was interested in describing his process of investigation into the execution of a Saudi princess. His focus meant that the docudrama was not an exploration of a different culture, but a personal search for understanding. However, this indirect approach was not made explicit to the audience. My analysis of Death of Princess has highlighted that such indirect narrative is an inappropriate style to adopt in attempting to present one culture to another through the documentary form.

Thomas's decision to employ a vicarious narrative style had a number of consequences. Most importantly, it required that the docudrama employ a first-person perspective throughout, foregrounding Thomas's personal interpretation of Saudi culture. The audience was not placed in the role of first-hand experiencers of events, but this distinction was never explicitly made within the documentary itself. As a result, the audience was likely influenced by Thomas's personal interpretation of Saudi culture. In focusing on his investigation process, Thomas assumed a knowledge of the culture on the audience's part. The first-person perspective that Thomas employed was not well suited to providing background information about the Islamic religion or Saudis' role in the Islamic world. Without this background information, the audience had no context for understanding the events recreated in the docudrama. As a result, Death of a Princess presented details without organizing them into a coherent, explicit explanation of different cultural values.

Although each individual segment of the docudrama might have been an accurate account of Ryder's interviews, the combination and arrangement of the statements was unbalanced and unrepresentative of Arab/Islamic culture as a whole. Most obviously, an extreme case was used as a symbol for a whole culture. The princess's execution was not representative of the whole Islamic sociocultural context. It is extremely unusual for a Saudi woman to be publicly executed. 
By choosing the execution of a Saudi princess as the primary symbol for the culture, Thomas focused on an unrepresentative aspect of that culture. The execution was likely to capture an American audience's attention and make Thomas's docudrama a commercial success; it was not, however, a symbol that captured the essence of the role of women in that society. Many more positive aspects of the society were ignored that could have been included to promote a better understanding between the two cultures.

Death of a Princess made a number of negative implicit value judgments. The film implied that the Saudi royal family was completely corrupt. This corruption extended not only to individuals, but also to the whole Saudi political system. The conservative Islamic values that the Saudis preached were not practiced by the characters portrayed in the film. Islamic conservatism only hid the immorality of the royal family. Instead of accepting their own weaknesses, the Saudis blamed Western influence for their social problems.

Saudi women were depicted as oppressed by the culture's social and religious values. The status of women was that of slaves, unable to travel freely or make basic decisions about their lives. The strict rules governing Saudi women were not protections, but a means of maintaining political control over the masses. In Death of a Princess, families were portrayed as being in the process of disintegration. Children were being raised by nannies, and husbands fled to the West while their wives remained caged in palaces. The life of a royal princess was one of boredom and uselessness, relieved only by the excitement of casual affairs.

Death of a Princess also implied that the Islamic religion was brutal and cruel. The Muslim religion was depicted negatively, because the execution was the only aspect of the religion that was featured. The docudrama did not represent the extent of other religious observations in a country that is proud of its heritage as the birthplace of Islam. Without a broader knowledge of Islam, a Western viewer would not understand the importance of Saudi Arabia in the Muslim world as the protector of the holy places of Islam. Saudis see their role in the Islamic world as a privilege they value highly. Death of a Princess explained Islamic attitudes toward public executions; it did not even allude to the many positive aspects of the Muslim community. While Thomas constantly asserted his interest in "the facts," as my analysis has indicated, this concern was not evident in the documentary form he chose or in the way he selected his interviewees. Most of Thomas's 
informers were not Saudi women or Saudi citizens, but other Arabs. The differences between the cultural characteristics of Saudis and other Arabs were never articulated. Thomas turned predominantly to non-Saudis or to Westerners to explain the events. As a result, Western or nonSaudi interpretations were foregrounded.

The range of different social classes in Saudi society was not represented in Thomas's investigation. He concentrated exclusively on the wealth and power of the upper class, and excluded any consideration of average Saudi citizens. Ordinary Saudi women were never interviewed, and yet Thomas drew implicit conclusions about their lives, even though he was focusing on royal princesses. Thomas attempted to generalize to the whole culture based upon a sample that was unrepresentative.

On a purely formal level, Death of a Princess was flawed. The indirect narrative style that Thomas adopted confronted the audience with many conflicting versions of the "facts" of the princess's story. These competing versions were resolved only on an implicit rather than an explicit level. By the end of the docudrama, Thomas was still confused about the meaning of the event and the whole cultural context surrounding it. Because there was no clear resolution in the docudrama, the audience was likely to be confused about the interpretation they should apply to Saudi culture. Death of a Princess failed to meet the expectations of the narrative format it employed. A good story has a clear ending. Death of a Princess did not meet this expectation. As Nichols explains, "indirect address invites risks of incomprehensibility" (183). Death of a Princess might well be incomprehensible to an audience that was looking for the competing versions of the story to be resolved on an explicit level. Only my analysis of the implicit meaning in the images has indicated the consistency throughout the film of the negative judgments applied to Saudi culture.

Although Thomas documented his personal search for understanding, his docudrama did not lead the American audience to a greater understanding of a different culture. The vicarious narrative style Thomas employed featured his personal interpretations. The culture he examined was secondary to his individual search for comprehension. There was little recognition that a consequence of this documentary approach might be that Western standards would be applied to judge Saudi culture. Thomas's docudrama interpreted the execution from a Western perspective, and it never successfully compared Saudi values with Western ones. Consequently, 
Death of a Princess was not effective in introducing one culture to another. It was effective, however, in sensationalizing one dramatic incident that was an extreme aspect of a whole culture.

My analysis of Death of a Princess leads one to question Thomas's explicit statement that the docudrama was intended as a "serious and concerned" journey into Saudi culture ("Furor" 32). An analysis of the textual content of the docudrama has indicated a concern with dramatic symbols that would attract attention. There were few indications, however, that Thomas was concerned with understanding the execution within the context of Saudi culture. The unquestioned cultural assumptions in the docudrama prompted vehement criticism from Saudis, who complained that the film presented grossly misleading views of Saudi Arabia, its culture, religion, and royalty ("A Saudi Squall" 30). As this analysis has indicated, Saudis' concerns about the content of the film were legitimate. My analysis of implicit values in the film has indicated that Thomas did not make a balanced presentation of the culture. Negative and one-dimensional images were consistently used to portray Saudis and their religion. Most of the stereotypes that Arabs have complained about were present in this docudrama. Death of a Princess was a classic example of the kinds of media message that third world nations hope to prevent through the application of the New World Information Order they have proposed.

\section{References}

Al-Hegelan, N. (1983). Women in the Arab World. Washington, D.C.: Saudi Arabian Information Office, The Royal Embassy of Saudi Arabia.

Al-Nowais, H. E. A. (1980). Under Secretary, Ministry of Information and Culture, United Arab Emirates.

"Welcome to the Delegates. The Arab Image in Western Mass Media (pp.11-13). London: Outline.

The American-Arab Anti-Discrimination Committee (ADC). (1984, March 15-18). "Media Perceptions of the Arab World." Remarks at the ADC Annual Convention, Washington, D.C.

Berelson, B., \& Steiner, G. A. (1964). Human behavior: An inventory of scientific findings. New York: Harcourt, Brace, and World, Inc.

Furor Over a T.V. Death. (1980, April 21). Time, pp. 32, Col. 1.

Hopkinson, T. (1980). The Mass Media: Are Common World Standards Possible? The Arab Image in Western Mass Media (pp. 29-37). London: Outline.

Lippmann, W. (2017). Public opinion. Routledge.

Lippman, W. (1971). The World Outside and the Pictures in Our Heads. The Process and Effects of Mass Communication. Eds. Wilbur Schramm and Donald F. Roberts. Chicago: Univ. of Illinois Press, 1971, pp. 265-286. 
Nichols, B. (1981). Ideology and the image: Social representation in the cinema and other media (Vol. 256). Bloomington: Indiana University Press.

O'Connor, J. J. (1980, May 11). Memorial for a Dead Princess. New York Times, pp. 37, Col. 1.

Patton, B. R., \& Giffin, K. (1981). Interpersonal Communication in Action (3rd ed.). New York: Harper and Row. Shaheen, J. (1980). The American Media and the Stereotyped Arab. The Arab Image in Western Mass Media. London: Outline.

Shaheen, J. (1981). Images of Saudis and Palestinians: A review of major documentaries. Television Coverage of the Middle East. Ablex, Norwood, NJ.

Thomas, A. (1980). prod. Death of a Princess [Transcript]. WORLD, prod, for PBS by WGBH Boston.

Webster, N., \& Gove, P. B. (1968). Webster's Third New International Dictionary of the English Language: Unanbridged: Utilizing All the Experiences and Resources of More Than One Hundred Years of MerriamWebster Dictionaries. 